\title{
O TAL DE NATAL: REIVINDICAÇÃO POR DIREITO TRABALHISTA E ASSASSINATOS DE CAMPONESES. PERNAMBUCO, 1963
}

The Christmas Bonus: demand for labor law and the killings of peasants. Pernambuco, 1963

\section{PABlo FRANCISCO DE ANDRAde PORFÍRIO}

http://dx.doi.org/10.1590/\$2178-14942016000300010

Pablo Francisco de Andrade Porfírio é mestre em História pela Universidade Federal de Pernambuco, doutor em História Social pela Universidade Federal do Rio de Janeiro e professor do Colégio de Aplicação da Universidade Federal de Pernambuco (pabloporfirio@hotmail.com).

Artigo recebido em 23 de agosto e aprovado para publicação em 7 de outubro de 2016. 


\title{
RESUMO
}

Este artigo toma o assassinato de cinco trabalhadores rurais na esplanada da Usina Estreliana como ponto de partida para a análise da luta por direitos trabalhistas na Zona da Mata de Pernambuco. Investiga-se como, além do uso da violência, articulou-se uma narrativa visual e escrita para classificar, qualificar e construir significados para a ação reivindicatória dos trabalhadores rurais. Apresenta-se ainda como esses significados, constituídos pelas ideias de desordem social e subversão, foram utilizados por setores da elite agrária para barganhar vantagens junto ao governo federal e fortalecer seu poder político.

PalaVras-CHAVE: trabalhadores rurais; violência; golpe de estado; fotografia; imprensa; história.

\begin{abstract}
This article takes the murder of five rural workers on the terrace of Estreliana sugar factory as a starting point for analysing the struggle for labor rights in Pernambuco's Forest Zone. It investigates how, besides the use of violence, a visual and written narrative was articulated to classify, qualify and build meanings for the vindicatory action of the peasants. It also presents how these meanings, constituted by the ideas of social disorder and subversion, were used by sectors of the agrarian elite to seek benefits from the federal government and strengthen their political power.
\end{abstract}

KeYwORDs: rural workers; violence; coup d'état; photography; press; history.

\section{RÉSUMÉ}

Cet article prend l'assassinat de cinq travailleurs ruraux qui a eu lieu sur l'esplanade de I'Usine Estreliana comme point de départ pour l'analyse de la lutte pour les droits du travail dans la zone forestière de Pernambuco. On étudie comment, au-delà de l'usage de la violence, un récit visuel et écrit a été articulé afin de classer, qualifier et construire des sens pour les revendications des paysans. On présente aussi comment ces sens, constitués par les idées de désordre social et subversion, ont été utilisées par des secteurs de l'élite foncière pour marchander des avantages auprès du gouvernement fédéral et renforcer leur pouvoir politique.

Mots-CLÉs: travailleurs ruraux; violence; coup d'état; photographie; presse; histoire. 


\section{INTRODUÇÃO}

R ibeirão, Mata Sul de Pernambuco, 7 de janeiro de 1963. Era manhã de uma segunda1.-feira. Quase uma centena de trabalhadores rurais, homens e mulheres, e algumas crianças, dos engenhos São Miguel, São José dos Palhados e Esperança marcharam em direção ao escritório da Usina Estreliana, pertencente ao deputado federal pelo Partido Trabalhista Brasileiro (PTB) José Lopes de Siqueira Santos (Diário de Pernambuco, 8/1/1963: 7; Última Hora, 8/1/1963: 4).

0 usineiro atuava como um importante líder político da elite agrária ${ }^{1}$ de Pernambuco. Era ainda conhecido por suas práticas de violência contra trabalhadores e moradores da região. Costumava andar com um "cipó de boi", chicoteando publicamente os empregados quando julgava necessário. ${ }^{2}$

Os trabalhadores que se dirigiram à Estreliana naquela segunda-feira já deviam ter escutado as histórias de violência envolvendo José Lopes ou mesmo presenciado alguma manifestação do seu poder repressivo ao punir trabalhadores. Ainda assim, vários deles deixaram suas casas e afazeres e foram tratar com o usineiro. 0 que teria levado dezenas de pessoas ao escritório da usina? Um dos trabalhadores presentes era Antônio Farias da Silva, que havia sido convidado a participar do grupo por Zacarias Batista do Nascimento. 0 convite fora feito durante uma conversa entre os dois na noite do domingo. ${ }^{3}$

Quando Antônio Farias, pai de dois filhos, saiu de casa na manhã daquela segunda-feira, disse à sua esposa que ia para a Usina Estreliana receber "um tal de natal". No dia anterior, Zacarias Batista lhe havia dito que esse "tal de natal era de lei e que o patrão tinha que pagar". Essa não era uma informação totalmente nova para Antônio. Alguns dias antes, outro Antônio, de sobrenome Gomes e vigia do engenho Esperança, também pertencente ao usineiro José Lopes, já tinha Ihe contado essa história do "tal de natal". Segundo o Diário de Pernambuco e o Jornal do Commercio, foi Antônio Gomes quem liderou o movimento.

0 "tal de natal" era o abono de natal ou 13ㅇsalário. 0 pagamento desse salário extra mobilizou os camponeses até o escritório da usina. Foi a Lei no 4090, de 13 de julho de 1962, que instituiu o direito dos trabalhadores de receber o pagamento desse benefício. Para as pessoas que foram ao escritório da Estreliana circulava a notícia de que existia uma carta 
assegurando o direito de receber o "tal de natal". Zacarias Batista havia comentado com Antônio Farias sobre a existência desse documento e argumentado que para receber o dinheiro era necessário que todos fossem tratar com o usineiro. Antônio Farias nunca leu ou escutou a leitura da carta. Ele, entretanto, afirmou ao jornalista do Jornal do Commercio: "Eu sei, doutor, que tinha uma carta. Eu vi de longe" (Jornal do Commercio, 8/1/1963:15).

Naquela manhã de janeiro de 1963, quando José Lopes chegou ao escritório, interpelou os camponeses sobre o que eles desejavam e quem era o líder do movimento denominado por ele de grevista (Porfírio, 2009: 80). 0 diálogo não durou muito. Foi interrompido por vários disparos de armas de fogo. Cinco camponeses morreram. Existe uma versão de que alguns trabalhadores tentaram atingir o usineiro com um facão e por isso houve uma reação dos empregados da Estreliana, que teriam saído em defesa do patrão.

Essa narrativa dos acontecimentos, apresentada de modo mais ou menos uniforme pelo Diário de Pernambuco e o Jornal do Commercio, informa que houve um conflito e dele resultaram cinco trabalhadores mortos. Dois funcionários da usina - Severino Marinho de Souza e Antônio Mariano -, que teriam defendido o usineiro, ficaram feridos por golpe de faca peixeira. Porém a própria reportagem do Diário de Pernambuco sobre o caso enfraquece a tese do conflito ao descrever como os trabalhadores, que foram reivindicar o 13ㅇsário, foram mortos: "Ernesto Batista do Nascimento e seu filho, João Batista, tombaram logo no local do tiroteio, enquanto Israel Batista do Nascimento (com tiro no tórax), Zacarias Batista do Nascimento (dois tiros de fuzil nas costas e um na perna direita), Antônio Farias da Silva (dois tiros de fuzil nas costas)" (Diário de Pernambuco, 8/1/1963: 7) foram levados para o hospital na cidade vizinha, Escada.

Os tiros de fuzil demonstram como o usineiro dispunha de um pesado armamento. A forma como os camponeses foram baleados, pelas costas, indica que eles provavelmente estavam tentando fugir do local ou mesmo que foram atingidos sem qualquer chance de defesa. Isso desqualifica a ideia de conflito, que ainda deve ser questionada pelo fato de que os capangas dos usineiros tinham armas - fuzis -, enquanto os camponeses carregavam apenas seus instrumentos de trabalho. Os fuzis foram disparados para matar os trabalhadores e não apenas para proteger o usineiro, como defenderam os textos do Diário de Pernambuco e o Jornal do Commercio. A própria reportagem deste último indicava essa questão quando reproduziu mais um trecho da entrevista dada pelo camponês Antônio Farias: "Tantos tivessem, morriam, doutor. Se não morreu mais gente foi porque tudo correu" (Jornal do Commercio, 8/1/1963: 15).

Esse trabalhador falou ao repórter do jornal quando estava internado na enfermaria do hospital da cidade de Escada. Foram suas últimas palavras antes de falecer, vitimado pelos disparos de fuzil. 


\section{A MORTE NA $1^{\text {A }}$ PÁGINA}

notícia da morte dos trabalhadores foi estampada na primeira página do Diário de
Pernambuco e do Jornal do Commercio no dia 8 de janeiro de 1963. Ocupou ainda uma página inteira dos seus Primeiros Cadernos. Entre os dias 8 e 9 de janeiro, o Diário de Pernambuco publicou 10 fotografias relacionadas diretamente ao ocorrido na usina, enquanto o Jornal do Commercio divulgou 7 imagens. Os dois periódicos eram os de maior tiragem e circulação no estado, com editoriais alinhados aos discursos da elite agrária. ${ }^{4}$

Neste artigo, a fotografia não é tomada como uma ilustração do ocorrido. É analisada como uma fonte documental, e por isso, segundo John Mraz (2015: 14), é necessário saber quem a produziu, conhecer o momento dessa produção e da publicação, suas intenções e usos sociais. Tais fontes devem ser analisadas, como indica Cora Gamarnik (2015: 251), como parte de um processo histórico e político, mas também como seu produto, procurando-se entender como tal processo as tornou possíveis.

Não consegui identificar o autor das imagens apresentadas a seguir. Nesse caso, como aponta Alberto Del Castillo (2012), pode-se recorrer aos editoriais dos jornais para investigar as engrenagens políticas e editorias que colocaram as imagens em circulação, formando uma narrativa visual. As imagens, segundo Gruzinski (2006), são como um veículo de poder e de resistência, que desenvolve um pensamento, oferece uma matéria específica tão densa como o texto. Cria, como denominamos, uma narrativa visual. Nesta narrativa interessa a análise, como ainda afirma Gruzinski (2006:17), "do programa e das políticas das imagens, o desenrolar das intervenções múltiplas que ela acarreta ou antecipa, os papéis que assume numa sociedade".

Mais ainda, as fotografias publicadas nos jornais, como alerta Cora Gamarnik (2015), têm o poder de destacar, condensar e simbolizar fatos e assim se transformam em instrumentos privilegiados de produção de sentido. No caso em estudo, será analisado como as fotografias dos trabalhadores rurais foram instrumentalizadas para produzir a subversão, definir o crime, apresentar o cidadão suspeito, instalar o medo, fatores que procuraram justificar, para a opinião pública, a violenta repressão da elite agrária aos movimentos reivindicatórios. Assim, considera-se que essas fotografias publicadas foram parte de uma batalha simbólica (Gamarnik, 2015: 226), que desejava tornar hegemônica a narrativa na qual as mobilizações dos trabalhadores pelo cumprimento dos direitos trabalhistas adquiriam o sentido da ilegalidade.

Ainda sobre a circulação das fotografias nos jornais, o historiador Alberto Del Castillo (2012: 17) afirma que o método de análise deve investigar "a escolha das imagens publicadas, sua disposição e sistematização através de distintas sequências para dar forma a um discurso visual que deseja persuadir o leitor em torno de certo tipo de mensagem". A narrativa 
visual dos periódicos sobre os acontecimentos na Usina Estreliana destacou, principalmente, os personagens envolvidos no caso. 0 Diário de Pernambuco divulgou uma sequência de três fotografias na parte inferior direita da sua primeira página no dia 8 com a legenda: "Quatro mortos e três feridos num conflito em Ribeirão". As imagens foram produzidas pela equipe de reportagem do jornal, não sendo informado o nome do fotógrafo. Sobre cada imagem publicaram-se as seguintes informações: a primeira retratava José Lopes falando sobre o conflito; a segunda apresentava o diretor do hospital de Escada pedindo garantias ao delegado contra uma possível invasão das Ligas Camponesas ao local; enquanto a última representava o flagrante de alguns trabalhadores presos.

Figuras 1 e 2: Diário de Pernambuco, 8 de janeiro de 1963, 1a página. Quatro mortos e 3 feridos num conflito em Ribeirão.
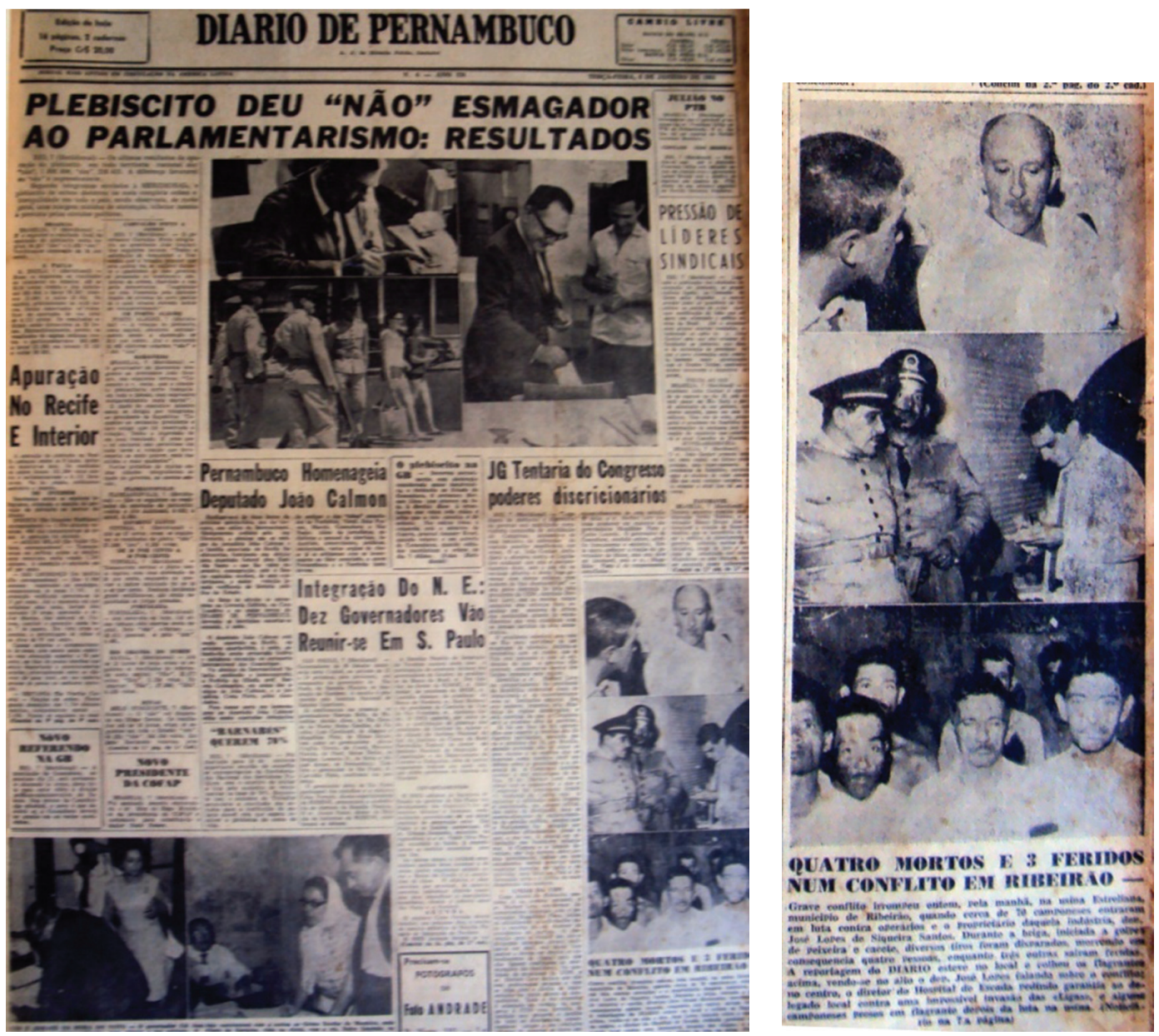
A sequência visual e a legenda narravam uma história do ocorrido, procurando informar ao leitor a atuação de cada personagem. 0 usineiro aparecia em destaque, contando sua versão dos fatos ao repórter. Em seguida, surgia a polícia, acionada para garantir a dita ordem social e a segurança de José Lopes, representado como a vítima da situação. Mas também, segundo a reportagem, os policiais deveriam proteger o hospital de Escada, onde estavam internados os capangas do usineiro, contra uma possível ação das Ligas Camponesas. Essa informação colocava as Ligas e seus integrantes no lugar do criminoso, condição representada pela última imagem, que mostrava as pessoas presas logo após o acontecimento da manhã do dia 7, ou seja, alguns dos trabalhadores rurais que tinham ido reivindicar o pagamento do 13ํㅗalário.

No dia seguinte, mais uma fotografia sobre o caso da Usina Estreliana ocupou o centro da primeira página do Diário de Pernambuco. Sua legenda dizia: "A tragédia da 'Estreliana'" . O texto que a seguia informava ter sido a "sensacional fotografia" conseguida pela equipe de reportagem da TV Clube, pertencente ao grupo Diários Associados, mas não informava o nome do seu autor. Ainda de acordo com o texto, na foto apareciam as vítimas do ocorrido.

Uma das conclusões mais imediatas, ao se analisar a imagem, é a de que se trata de uma fotografia montada. Ou seja, que se organizou a disposição dos corpos, chapéus e das ditas armas, peixeiras ainda nas bainhas, em conformidade com os interesses da representação. Nesse caso, o usineiro e parte da imprensa desejavam demonstrar que a violência dos camponeses, a agitação social e a subversão da ordem eram crescentes nos canaviais de Pernambuco. Essa conclusão inicial indica outro nível de análise para os usos da imagem. A fotografia aparece como um instrumento de representação do real, que evidenciaria as práticas subversivas e os seus agentes. Nesse período, era comum jornais e revistas da imprensa nacional e também internacional publicarem reportagens nas quais afirmavam estar em desenvolvimento um processo de cubanização no Nordeste do Brasil, com destaque para Pernambuco (Dezemone, 2016: 5; Porfirio, 2016: 89).

Personagens antes anônimos - como os trabalhadores rurais - ganhavam as páginas da imprensa e eram tema dos seus editoriais, sendo integrados à engrenagem que fazia circular a imagem da desordem social. Dar-se-ia a ver, por meio da fotografia, um ambiente subversivo para indicar os cidadãos suspeitos. Na fotografia de 1a página do caso ocorrido na Usina Estreliana, os instrumentos utilizados no eito pelos trabalhadores rurais, colocados deitados e ordenados ao lado dos seus donos caídos, foram tomados como as armas com as quais se tentara matar o usineiro José Lopes. Identificava-se, assim, a prática da violência e a quebra da ordem pelos trabalhadores. 
Figura 3: Diário de Pernambuco, 9 de janeiro de 1963, 1ạ página.

A tragédia da Estreliana.

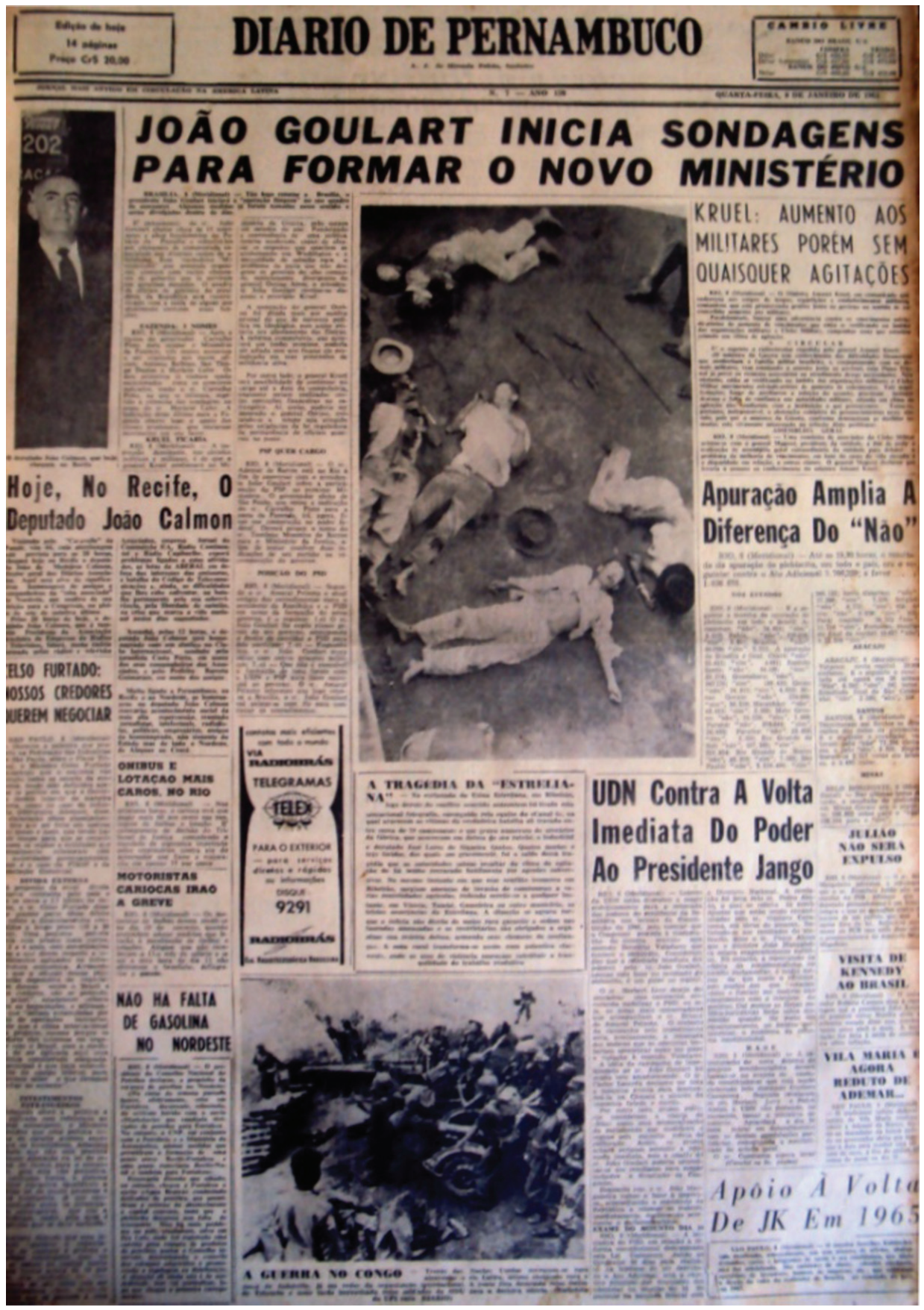


Jornais como o Diário de Pernambuco e o Jornal do Commercio já publicavam, desde o início dos anos 1960, imagens de trabalhadores rurais, relacionando-os a atos classificados como criminosos. Em janeiro de 1960, no município de Ribeirão, o mesmo onde se localizava a Usina Estreliana, três trabalhadores rurais foram presos acusados de incendiar canaviais dos engenhos. Os dois jornais publicaram a mesma fotografia nas suas reportagens sobre o caso.

O Diário de Pernambuco chamava os trabalhadores de incendiários. Identificava-os como criminosos. A fotografia nas reportagens apresentava-os, incluindo uma criança, ladeados por policiais, e assim reforçava esse lugar do crime e da desordem social, contraposto e reforçado pela ordem e pela legalidade que os policiais representariam. ${ }^{5}$

Os relatórios e os interrogatórios produzidos pelos agentes da Delegacia de Ordem Política e Social (DOPS-PE) sobre esse caso podem ser cotejados com a notícia veiculada pela imprensa. Foram presos e interrogados os trabalhadores rurais Possidônio Alves da Silva, Severino José da Silva, Severino Martins da Silva e Jurandir Simão da Silva. A conclusão do sargento Severino Batista, responsável pela investigação, afirmava que os incêndios não eram rigorosamente criminosos. As lógicas do sentido de crime apresentadas pela imprensa e pelo relatório do sargento eram distintas. Em um dos depoimentos, o trabalhador admitiu ter queimado a cana para que o dono do engenho fosse obrigado a cortar. Desse modo, o cortador de cana poderia conseguir algum dinheiro emergencial para o sustento da família. 0 sargento ressaltou que a situação desse trabalhador era de extrema pobreza, produzindo assim outra leitura e uma justificativa para aquele ato classificado por parte da imprensa como criminoso. ${ }^{6}$ Mesmo que as conclusões desse relatório fossem divulgadas pelos jornais, é possível pensar que dificilmente se mudaria o entendimento de grande parte da opinião pública sobre esses eventos. Desde o início dos anos 1960, cada vez mais se fortalecia a percepção de que existia uma desordem social que tomava o estado por meio da ação de comunistas e líderes subversivos. Os incêndios eram mais uma prova dessa situação, divulgada cotidianamente pelos periódicos de maior circulação (Montenegro, 2004: 226).

A fotografia onde aparecem Possidônio Alves da Silva, Severino José da Silva, Severino Martins da Silva e Jurandir Simão da Silva ao mesmo tempo em que indicava os indivíduos suspeitos e criava uma contraposição entre estes e os representantes da lei, lançava mão também de uma estética que construía a desordem (Magalhães, 2008: 109). Os trabalhadores presos surgiam na fotografia com a aparência descuidada, um olhar triste e resignado. Os policiais vestiam uniformes alinhados, apresentavam suas armas e um olhar altivo. Essa configuração da imagem, presente em outras fotografias publicadas nos primeiros anos da década de 1960, individualizava esses trabalhadores a partir da ideia da desordem e, por conseguinte, do crime 
Figura 4: Diário de Pernambuco, 14 de janeiro de 1960, p. 5. Volante da P.M. capturou mais quatro incendiários de canaviais, em Ribeirão.

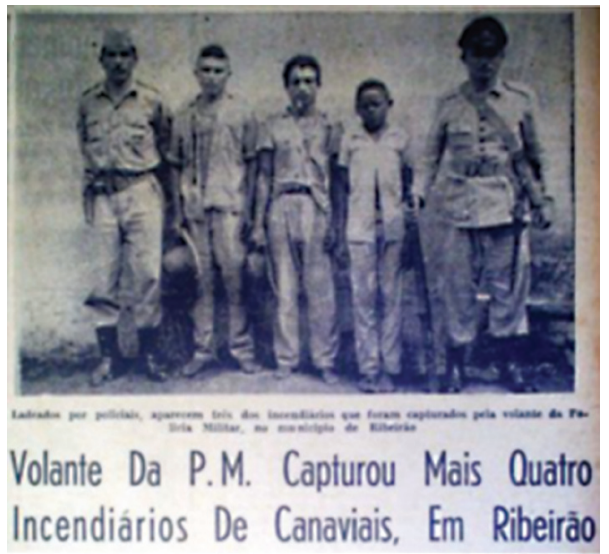

Figura 5: Jornal do Commercio, 14 de janeiro de 1960.

Incêndios nos canaviais: sargento faz relatório das atividades da volante.

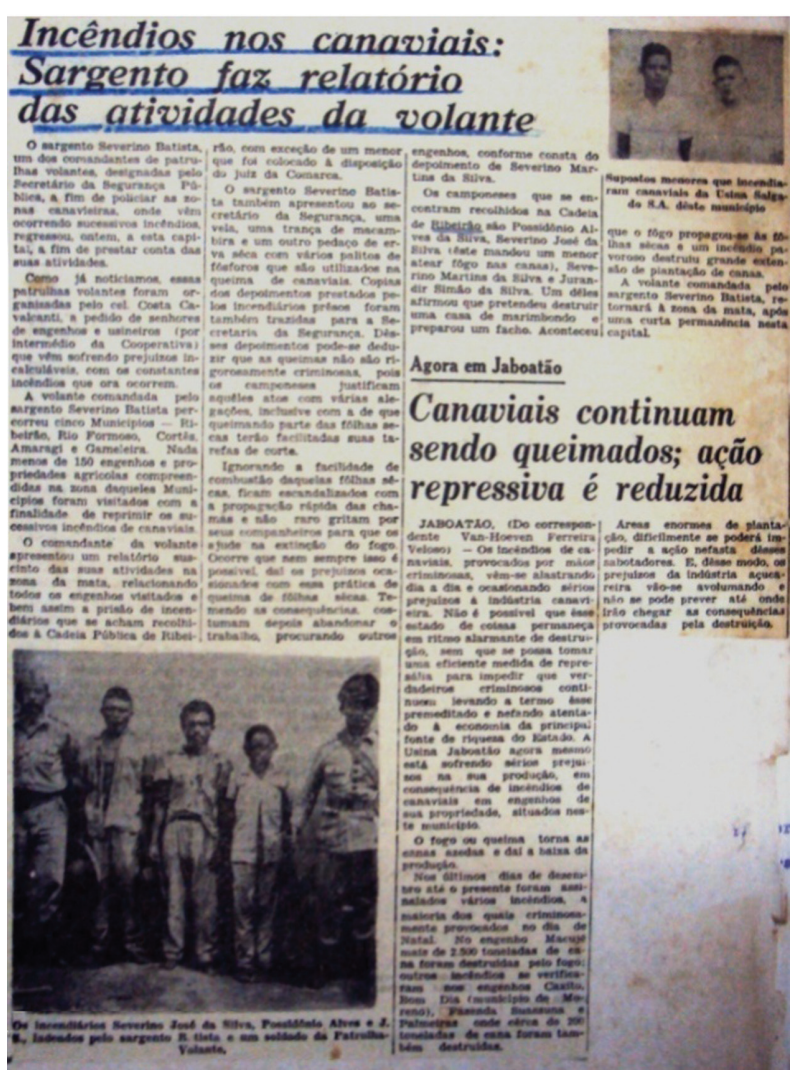


(Kossoy, 2013: 55). Quem mirasse essas fotografias nos jornais ou em outros suportes deveria ver criminosos.

Deve-se pensar que esse tipo de composição fotográfica criava uma narrativa visual sobre os trabalhadores rurais e seus movimentos sociais. A imagem dos camponeses baleados em frente ao escritório da Usina Estreliana, publicada com destaque na primeira página do Diário de Pernambuco, poderia também ser vista pelo leitor a partir da lógica dessa narrativa visual. Assim, a fotografia não retrataria pessoas assassinadas por capangas de usineiros. Apresentaria possíveis criminosos, ao menos indivíduos suspeitos, ou ainda trabalhadores que seguiam líderes de movimentos sociais, como Francisco Julião das Ligas Camponesas, considerados criminosos por parte da imprensa.

A "sensacional fotografia", como anunciava o Diário de Pernambuco, tinha um caráter "performativo", operava como documento testemunhal que captaria a realidade e a revelaria para o leitor (Gamarnik, 2011: 54). 0 fotógrafo atuaria como testemunha ocular da história. A imagem publicada apresentava um fragmento e o tomava como a evidência de uma realidade global (Kossoy, 2013: 55-56) de violência no campo produzida por líderes subversivos que mobilizavam centenas de trabalhadores para alcançar seus objetivos revolucionários.

Essa dita realidade capturada/fotografada ganhava sentido também na relação da imagem com os textos publicados no jornal. 0 leitor do Diário de Pernambuco do dia 9 de janeiro, após ver a fotografia na 1a página, poderia ler no editorial do periódico, na página três, a seguinte afirmação sobre o ocorrido na Usina Estreliana:

E somente uma cegueira irremediável lograria empanar o sentido derradeiro destes episódios: trata-se de plano maduramente executado, no sentido de apressar a subversão que vem a galope, atirando na liça a exaltação de instintos primários de uma patuleia desenfreada, habilmente manobrada por artífices da desordem, visando a destruir a ordem vigente - cheia de erros, sem dúvida, necessitando de revisão urgente e de base, mas, de qualquer modo, merecedora de respeito, porque alicerçada no disciplinamento jurídico ainda dominante que terá de ser substituída por etapas, sob pena de, aluída em seus fundamentos, dar lugar ao caos, à orgia, à subversão de tudo.

O sentido primeiro oferecido para o ocorrido consistia, de acordo com o editorial, na execução de um plano subversivo que visava destruir a ordem. Tal plano se utilizava de "instintos primários de uma patuleia desenfreada", ou seja, a população de trabalhadores rurais pobres e ignorantes manipulada por líderes que desejavam implantar o caos.

Apesar de não descolar a imagem dos trabalhadores da ideia do crime ou da condição do suspeito - eram essa ideia e essa condição que justificavam a morte daquelas pessoas e 
sua exibição na imprensa -, o jornal apresentava outro nível de práticas e de discursos que colocava esses mesmos trabalhadores a serviço da subversão, orquestrada por líderes de uma corrente política revolucionária. Miguel Arraes, que seria empossado governador de Pernambuco no final daquele mês de janeiro, Francisco Julião, eleito deputado federal em outubro de 1962, e João Goulart, que acabava de recuperar seus plenos poderes como presidente ao derrotar o parlamentarismo no plebiscito realizado dias antes do assassinato na Usina Estreliana, formavam essa corrente.

Nas primeiras páginas do Diário de Pernambuco dos dias 8 e 9, onde foram publicadas fotografias sobre o ocorrido na Usina Estreliana, as manchetes destacavam a derrota do parlamentarismo e a formação da nova equipe de governo por João Goulart, que intensificaria as propostas das reformas de base, entre elas a reforma agrária (Gomes e Ferreira, 2014: 161): "Plebiscito deu 'não' esmagador ao parlamentarismo: resultados" e "João Goulart inicia sondagens para formar o novo ministério". Muitos leitores poderiam entender que a subversão da ordem avançava em nível local e nacional.

Especificamente sobre as mudanças políticas em Pernambuco, o editorial do dia 9 de janeiro (p. 3) afirmava:

Uma corrente política - os fatos ainda estão vivos na memória geral - adotou como linha de sua luta triunfante de conquista do poder, o programa revolucionário de apontar os donos de terras, sobretudo na mata, como os responsáveis supremos pelas desgraças da coletividade. [...] Natural, assim, que próximo a concretizar-se a hegemonia político-administrativa dos "donos" da nova cruzada, o meio rural, perigosa e criminosamente trabalhado, comece a movimentar-se, atacando engenhos e usinas, na sofreguidão incontida do vitorioso que vê tardar a consecução dos objetivos por que lutou e venceu.

A frente política de esquerda comandada por Miguel Arraes era acusada de promover a movimentação violenta do "meio rural" contra os latifundiários da Zona da Mata. Seus integrantes faziam dos trabalhadores rurais um joguete dentro do plano subversivo maior, que havia logrado conquistar a "hegemonia político-administrativa". Isso não significava retirá-los da condição de suspeitos e de criminosos, mas integrá-los à engrenagem que colocava a "subversão em marcha", como anunciava o título do editorial.

0 editor-chefe do jornal, Costa Pôrto, que por ocupar tal posição deve ter participado da escolha da fotografia estampada na 1a página do dia 9 de janeiro, anunciava em um pequeno artigo publicado no dia seguinte (p. 3):

A culpa maior, entretanto, não é desta pobre gente mas dos que se improvisam de líderes, de condutores, de "salvadores", estimulando-lhes os piores instintos, pregando a subversão às 
claras, construindo um fatal "plano inclinado" que ainda lhe vai dar dor de cabeça. Porque rompidos os diques, não há quem possa conter a massa doida e enfurecida. [...] Muito populista profissional deveria, a estas horas, estar com as barbas de molho: semearam-se ventos, agora é a vez de colher tempestades, que virão, ninguém se iluda, e quando vierem vamos ver quem Ihes escapa à ação destruidora.

0 texto de Costa Pôrto permitia ao leitor pensar que a ação do usineiro José Lopes e seus capangas, na manhã da segunda-feira 7 de janeiro de 1963, fora a de conter essa "massa doida e enfurecida" de trabalhadores rurais pobres mobilizados pelos que "se improvisam de líderes", combater seus "piores instintos" e a sua "ação destruidora", fato que seria comprovado pela "sensacional fotografia" publicada na 1ạ página do jornal. Era uma tragédia, contudo, necessária e justificada pela imprensa.

\section{Operativo Militar na MATA SUl}

inda no dia 9 de janeiro de 1963, outra fotografia sobre o acontecido na Usina Es-
policiais.

De acordo com a legenda, a imagem mostrava policiais contemplando mortos e feridos na esplanada da Usina Estreliana. É possível estabelecer uma aproximação entre esta composição fotográfica e as anteriores que apresentavam os policiais e os ditos incendiários dos canaviais. Na figura 7, entretanto, eram os policiais e os trabalhadores rurais que haviam, segundo o jornal, tentado matar o usineiro José Lopes ao reivindicar o pagamento do 13응 salário. Em certa medida, permanecia a composição da imagem que estabelecia uma oposição entre trabalhadores e policiais. Contudo, as pessoas suspeitas de serem criminosas, que antes apareciam com olhar resignado ladeadas pelos policiais, agora estavam no chão, mortas ou gravemente feridas. Os policiais, por sua vez, continuavam de pé, encarando a câmera do fotógrafo. Essa mudança de posição adquire significado quando relacionada com a alteração no quadro político provocada pelos resultados das eleições de outubro de 1962 e o dito avanço da subversão, da desordem e da cubanização, destacados pelos editoriais da imprensa. Ou seja, a "marcha da subversão" provocaria o recrudescimento da violência, com mortos e feridos. As vítimas do usineiro e de seus capangas passaram a ocupar as páginas dos principais jornais do estado, mas não para a denúncia da violência praticada pela elite agrária. Desejava-se anunciar a gravidade daquele momento e a forma como alguns usineiros, como José Lopes, atuariam frente à mobilização de trabalhadores rurais. 
Figuras 6 e 7: Diário de Pernambuco, 9 de janeiro de 1963, p. 7.

O conflito da Estreliana.

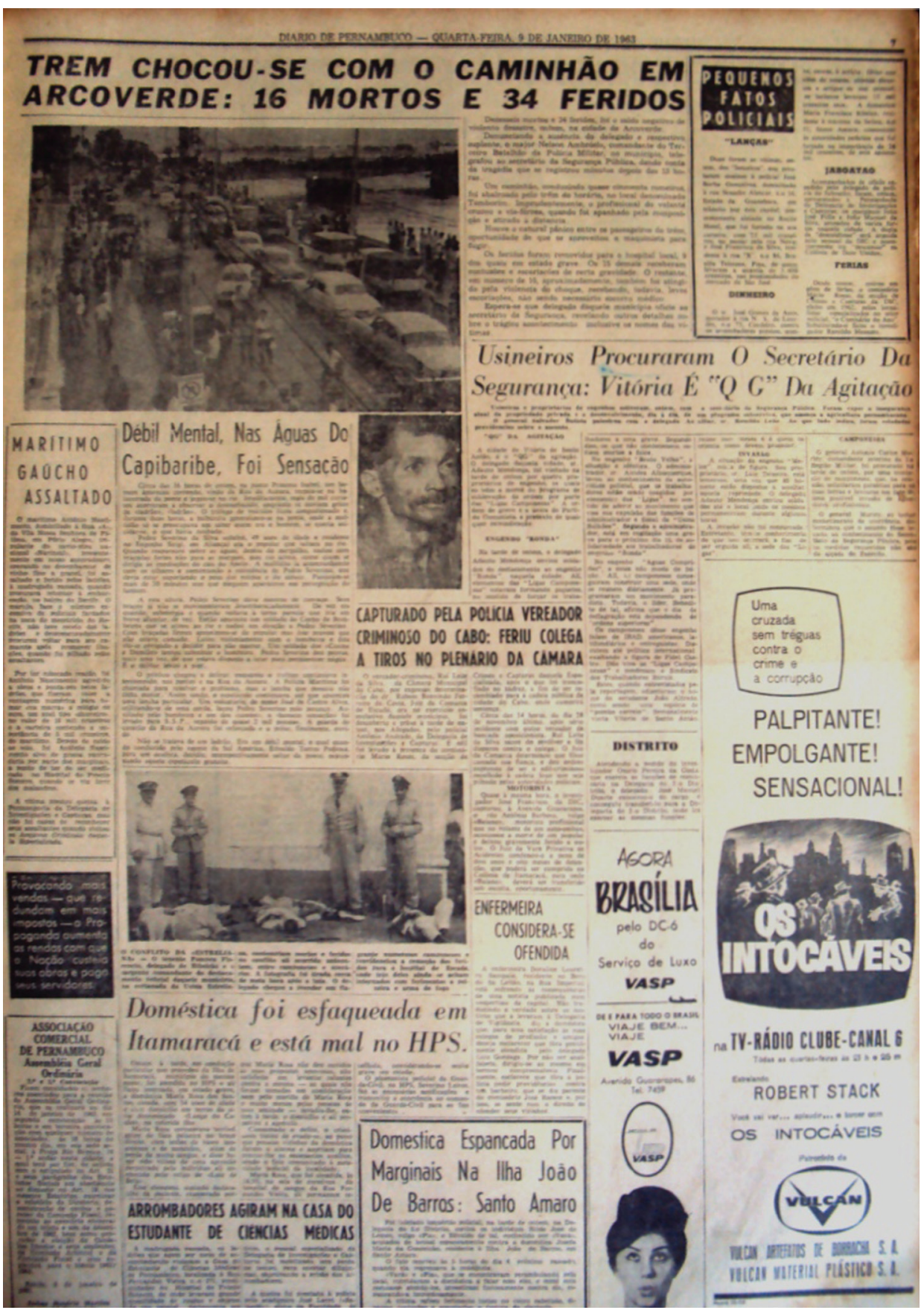




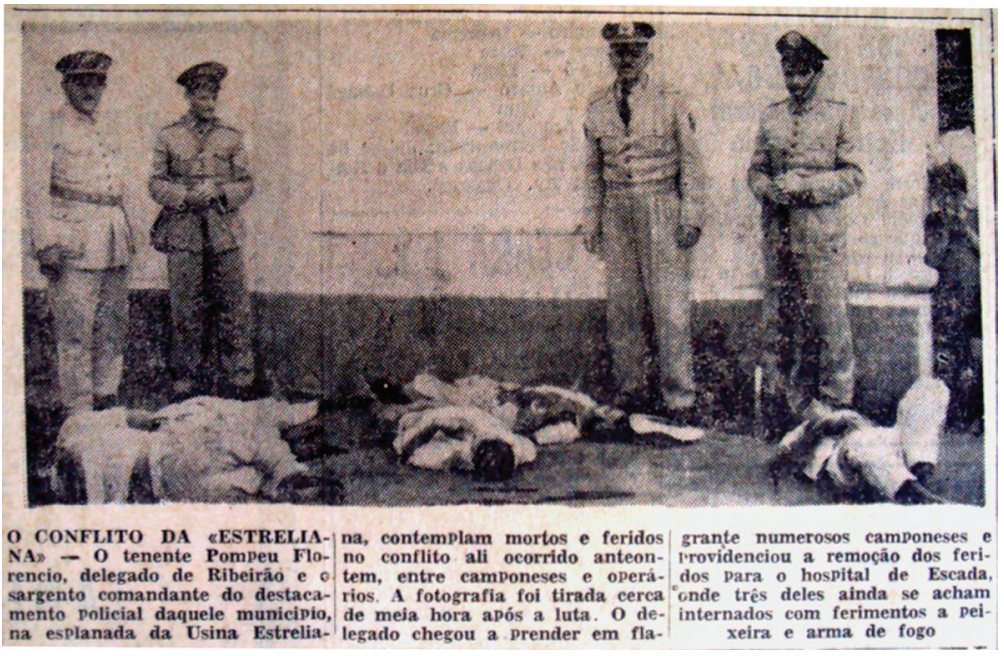

Após os assassinatos na Usina Estreliana, iniciou-se uma operação da polícia militar nos engenhos da Mata Sul de Pernambuco, atendendo ao pedido dos proprietários. O general Salvador Batista do Rêgo, secretário de Segurança Pública do governador Cid Sampaio, informava que a polícia estava pronta para atender a todos os donos de engenhos e usinas que estivessem, segundo ele, com suas propriedades e vidas sob ameaça. Ainda declarava à imprensa que os usineiros, na qualidade de industriais, poderiam armar legalmente seus vigias, formando uma "tropa de defesa contra a dilapidação do seu patrimônio" (Jornal do Commercio, 10/1/1963: 3).

Alguns jornais de Pernambuco e do Sudeste do Brasil, como O Globo, publicaram notícias, inclusive na 1a página, sobre o clima de medo e a desordem que se teriam instalado no meio rural de Pernambuco. Veicularam imagens de policiais se deslocando para a Mata Sul do estado e de pequenos batalhões fortemente armados constituídos pelos vigias dos engenhos e usinas.

A utilização da força policial do Estado por setores da elite agrária já era prática comum havia anos. 0 episódio na Estreliana foi utilizado com o fim de potencializar o uso do aparato repressivo pelos donos de engenhos e de usinas. Eles desejavam intensificar a repressão ao movimento de trabalhadores rurais, que se expandia pela atuação, por exemplo, dos sindicatos rurais organizados por comunistas e setores da Igreja Católica, e autorizados pelo governo João Goulart a partir de 1962 (Pereira, 2009). Segundo O Globo (11/1/1963: 6), Fábio Correia, deputado estadual pela União Democrática Nacional (UDN) e proprietário da usina Cachoeira Lisa, vizinha da Estreliana, na madrugada do dia 9 de janeiro seguira para suas terras acompanhado de uma volante da polícia militar de Pernambuco.

Ainda de acordo com o jornal, vários proprietários de terras pernambucanos haviam feito uma visita ao comandante da 7ạ Região Militar, General Antonio Carlos Murici. Pediram 
garantias do Exército para as suas propriedades e para as suas vidas, que estariam ameaçadas por integrantes das Ligas Camponesas. Segundo o jornal, o General Murici reconheceu a gravidade do momento, mas informou que o Secretário de Segurança Pública era quem tinha competência para oferecer as garantias pleiteadas.

A relação entre latifundiários e setores do Estado na repressão aos movimentos dos trabalhadores rurais era de colaboração naquele janeiro de 1963. A partir do mês seguinte, o novo governador, Miguel Arraes, tentou alterar essa relação, exigindo que a polícia deixasse de atuar sempre em favor dos proprietários e se posicionasse de modo a mediar os conflitos. Ou seja, a força policial não estaria mais à disposição para atender aos interesses particulares de usineiros e donos de engenho como era de costume (Callado, 1980; Page, 1972; Dabat, 2008).

Entretanto, a relação entre representantes da elite agrária e o Exército muito provavelmente se manteve e se fortaleceu durante o ano de 1963 e o seguinte. Apesar de O Globo publicar a informação de que Antonio Carlos Murici não iria atender às demandas por garantias dos latifundiários, sabe-se que estes se armaram cada vez mais fortemente. Segundo o ex-presidente do Sindicato dos Trabalhadores Rurais de Gameleira, José Sebastião, que em 1963 trabalhava como cabo nos canaviais desse município vizinho a Ribeirão, o arsenal existente nas mãos dos proprietários de terra era "pesado". 7

Uma entrevista concedida pelo médico Fernando Barbosa ao projeto Marcas da Memória, em 2011, oferece um indício de onde viriam essas armas. No início da década de 1960, Fernando era estudante do curso de medicina, integrante do Partido Comunista e ainda participava das Ligas Camponesas. Durante algum tempo, nesse período, ele serviu ao Exército. Em um determinado dia, estando na Ajudância Geral do IV Exército, em Recife, ouviu um diálogo entre dois militares que debatiam como as armas enviadas para usineiros e senhores de engenho na Mata Sul de Pernambuco regressariam às Forças Armadas. Fernando recorda que a pessoa responsável por receber as armas oriundas do Exército e distribuí-las entre os proprietários da região era José Lopes de Siqueira Santos.

[...] quem tinha as armas eram os usineiros, porque eu estava na Ajudância geral do 40 Exército em 1961 e vi quando um Coronel, como era o nome dele meu Deus? Eu sei que ele discutia com o Bismarck e com o Albuquerque, por que que as armas estavam saindo da 7a Região Militar para entregar a José Lopes de Siqueira Santos na usina, e José Lopes distribuir com os usineiros da Zona da Mata Sul para combater os Sindicatos Rurais, como é que se ia recolher essas armas? Porque as armas não podiam ser emprestadas, armas privativas das Forças Armadas, não podiam ser emprestadas a civis. Eu sei que os três oficiais, coronéis, estavam discutindo isso, e eu caladinho trocando de roupa, eles não me viram. E eu passei isso para o pessoal. Eu digo: olhe, está acontecendo isso, eles estão distribuindo armas, e a pessoa que está pegando as armas é José Lopes de Siqueira Santos (Projeto Marcas da Memória, 18/10/2011: 18-19). 
É preciso ainda encontrar outras fontes documentais sobre a relação entre José Lopes e os militares do IV Exército em 1963. São necessários também outros documentos para formular uma análise mais consistente do que teria sido essa associação operacional e repressiva entre o Exército e os latifundiários em Pernambuco. A impossibilidade de acessar os arquivos do IV Exército é um dos principais fatores que dificultam o desenvolvimento dessa linha interpretativa. Porém pode-se tomar a memória de Fernando Barbosa como indício do funcionamento dessa associação. Esse indício é reforçado ao ser relacionado com a notícia d'O Globo de que senhores de engenho de Pernambuco procuraram o General Antonio Carlos Murici, em janeiro de 1963, para pedir o apoio do Exército na repressão aos trabalhadores rurais. Se por um lado o governador Miguel Arraes tentava barrar o uso patrimonialista da Polícia Militar de Pernambuco pelos latifundiários, por outro o Exército e integrantes da elite agrária pareciam manter e talvez reforçar suas relações colaborativas e repressivas.

Essa é uma análise construída a partir dos documentos já apresentados neste tópico em diálogo com a linha de pesquisa apresentada, por exemplo, no livro Retrato da repressão política no campo (Carneiro e Cioccari, 2011: 27), que procurou romper o silêncio sobre a repressão praticada no meio rural, caracterizando-a como complexa e diversificada em suas formas, constituída por ações de impacto e ostensivas, como assassinatos, e outras mais sutis, cotidianas, e além disso localizando-a temporalmente antes do golpe civil-militar de 1964 e definindo-a como uma aliança entre as oligarquias rurais e as forças do Estado, que seria exacerbada no regime militar (ver também Viana, 2013 e Koury, 2010: 206). ${ }^{8}$

0 assassinato de trabalhadores na Usina Estreliana deve ser relacionado ao funcionamento desse operativo repressivo, que, entre outros objetivos, tentava barrar a luta pela aplicação da lei que concedia direitos trabalhistas e, por conseguinte, a construção de uma cidadania para homens e mulheres pobres do meio rural.

\section{ReUnião NO IAA}

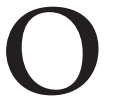

s trabalhadores que se dirigiram à esplanada da Usina Estreliana em janeiro de 1963 reivindicavam o pagamento do $13^{\circ}$ salário. É possível que nem todos soubessem sobre o tal abono de natal, mas alguns integrantes do movimento levavam consigo um ofício da Delegacia Regional do Trabalho, confirmando o direito de recebimento do dinheiro extra (Jornal do Commercio, 8/1/1963: 3).

A Lei no 4.090, de 13 de julho de 1962, instituiu o direito de os trabalhadores receberem o pagamento de um salário extra. Esse direito foi rapidamente incorporado às reivindicações de parcela dos trabalhadores, tanto que, poucos meses depois da promulgação da lei, 
em janeiro de 1963, um grupo foi reivindicar o recebimento do benefício ao dono da Usina Estreliana. Pode-se pensar que eles conheciam parte da legislação trabalhista e sabiam como operá-la. Tal situação pode ter sido influenciada pelos vários anos de atuação das Ligas Camponesas. Seu principal líder, Francisco Julião, organizava os trabalhadores para lutarem por seus direitos na Justiça Civil (Julião, 2009: 141), já que antes de 1962 não existiam Juntas de Conciliação e Julgamento da Justiça do Trabalho instaladas na Zona da Mata de Pernambuco. ${ }^{9}$ A reivindicação do pagamento do abano de natal já era uma pauta entre trabalhadores urbanos desde antes de 1962. Contudo, Antonio Montenegro (2013: 315) afirma que, para os trabalhadores da Zona da Mata de Pernambuco, "o pagamento do 13- tornou-se uma realidade conhecida de todos apenas depois da lei aprovada". Deve-se atentar para o fato de que desde o início da década de 1960 intensificou-se uma disputa pela organização e representação dos trabalhadores rurais nessa região. Além das Ligas Camponesas, comunistas e setores da Igreja Católica competiam para ocupar o lugar de liderança no movimento camponês com a organização dos sindicatos rurais (Montenegro, 2010: 99). As ações desses grupos contribuíram para a divulgação do direito de recebimento do 13ำ salário.

Alguns dias após o ocorrido na Usina Estreliana, Luis Serafim, uma das lideranças dos Sindicatos de Trabalhadores Rurais de Jaboatão, Moreno, São Lourenço, Paudalho e Glória de Goitá, afirmou ao Jornal do Commercio (10/1/1963: 3) qual o objetivo das mobilizações que estavam ocorrendo nos primeiros dias daquele ano, incluindo a realizada no município de Ribeirão:

Estamos fazendo um movimento reivindicatório do 13o mês e o pagamento do salário correspondente à região [... Não queremos violência e sim o que é nosso. Queremos os mesmos direitos que tem o operário da capital. Exigimos salário da região, oito horas de trabalho e descanso semanal.

Indagado pelo repórter por que não procuravam entendimento diretamente com os administradores das usinas, respondeu: "Preferimos, primeiro, manter entendimentos com 0 Delegado Regional do Trabalho". Naquele momento, o arbítrio do Estado parecia interessar mais aos trabalhadores.

Do lado dos usineiros, a novidade do 13ำ salário e as mobilizações dos trabalhadores reivindicando seu pagamento exigiam novas estratégias de ação, novos agenciamentos institucionais. Em alguns casos, como na Usina Muribeca, em Jaboatão, os proprietários buscaram negociar com os trabalhadores o pagamento do abono de natal (Montenegro, 2013: 317). Em Ribeirão, como se sabe, José Lopes tratou do assunto a bala. Além desse enfrentamento ou da negociação direta com os trabalhadores, os usineiros e donos de engenhos procuraram outros meios de ação. Um deles está registrado na ata da reunião de 9 de janeiro de 1963 realizada na sede do Instituto do Açúcar e do Álcool (IAA) na cidade do Rio de Janeiro. ${ }^{10}$ 
Desse encontro participou o presidente da Associação dos Fornecedores de Cana de Pernambuco e deputado estadual Francisco Falcão. Ele incluiu na pauta o tema do assassinato dos trabalhadores, perguntando aos demais participantes se havia legalidade e obrigatoriedade de pagamento do 13ำ salário naquele ano de 1963. E, caso houvesse, como ele seria realizado, visto que, segundo afirmou, os proprietários de terras não tinham orçamento disponível para tanto. ${ }^{11}$

A transcrição do debate em ata ocupa quase 20 páginas. 0 discurso inicial do presidente do IAA, Manoel Gomes Maranhão, revela a forma de tratar o tema por parte daquele órgão: "O fato ocorrido na Usina Estreliana, em Pernambuco, traduz a gravidade da situação nos estados, sobretudo no de Pernambuco e Alagoas, pois o acontecido naquela usina, de propriedade do nosso caro José Lopes, realmente merece maior atenção". ${ }^{12}$ Primeiro, a "gravidade da situação" se traduziu pelo que foi chamado de ações promovidas por agitadores políticos que tratavam de mobilizar os camponeses para realizarem atos violentos no meio rural. A luta por direitos trabalhistas era associada à ideia da desordem social tão presente nos editoriais e na narrativa visual veiculada por amplos setores da imprensa, como já demonstrado. Depois, a referência ao dono da Estreliana como "nosso caro José Lopes" indicava a relação de integrantes da elite agrária de Pernambuco, representada na reunião por Francisco Falcão, e setores do Estado, nesse caso o IAA. 0 usineiro era considerado vítima de agitadores, e as agitações sociais e políticas, como se vê no decorrer da ata, justificavam a necessidade de um apoio maior por parte do governo aos proprietários. 0 assassinato dos trabalhadores foi transformado em oportunidade para expor uma dita dificuldade da classe em saldar suas obrigações trabalhistas. Logo, o governo, em face da gravidade da situação, deveria intervir com novos financiamentos. Segundo reportagem publicada pelo jornal O Globo de 11 de janeiro de 1963 (p. 6), dois dias depois da reunião no IAA, "o Banco do Brasil em Pernambuco tomará providências para atender às usinas e engenhos que não tenham conseguido financiamento para o pagamento do 13 (sic) salário, com o que se tirará aos agitadores o pretexto para as ameaças e tumultos dos últimos dias".

Além disso, o presidente da Associação dos Fornecedores de Cana de Pernambuco conseguiu que fosse publicada nos principais jornais, no dia seguinte à reunião, uma nota de apoio do IAA à Associação. E por fim, logrou que o IAA, por meio do senhor José Ribamar, que foi identificado em ata como amigo do ministro do Trabalho, Benjamin Eurico Cruz, interpelasse o Ministério sobre o auxílio aos usineiros e senhores de engenho para o pagamento do 13ํsalário.

Por meio da ata de reunião do IAA, é possível entender como a mobilização dos trabalhadores rurais para exigir o cumprimento de um direito trabalhista foi convertida pelos patrões em uma oportunidade para barganhar benesses do governo, fossem elas linhas de crédito, fossem declarações públicas de apoio, e assim manter seu poder e mesmo fortalecê-lo. 


\section{CONSIDERAÇÕES FINAIS}

$\mathrm{O}$ assassinato de trabalhadores rurais em frente ao escritório da Usina Estreliana, suas representações na imprensa e seus usos políticos foram tomados neste artigo para a análise das estratégias utilizadas por usineiros e donos de engenhos contra as mobilizações políticas desses trabalhadores no início do ano de 1963. 0 caso em tela possibilitou identificar indícios de como, antes do golpe de 1964, representantes da elite agrária buscaram apoio de setores das Forças Armadas para executar a repressão aos trabalhadores. Tal questão indica a necessidade, como ressaltam os trabalhos de Ana Carneiro e Marta Cioccari (2011: 27), Mauro Koury (2010: 206) e Gilney Viana (2013), de se estudar a construção e o funcionamento dessa aliança operativa e romper um silenciamento sobre a repressão aos camponeses e seus movimentos políticos antes, durante e mesmo depois da ditadura instalada a partir de 1964.

Por meio do acontecimento na Usina Estreliana ainda foi possível investigar como se produziu uma narrativa visual que criminalizava os trabalhadores rurais e oferecia a justificativa para a execução de uma operação militar na Mata Sul de Pernambuco. Não se deve perder de vista que representantes da elite agrária souberam utilizar essa mobilização dos trabalhadores pelo recebimento do 13ㅇsalário para reforçar seu poder, em alguma medida ameaçado pelo movimento camponês. 0 uso da imprensa e a busca de apoio no Exército, na Secretaria de Segurança Pública de Pernambuco e no Instituto do Açúcar e do Álcool indicam as manobras e as estratégias aplicadas no fortalecimento desse poder.

A violência praticada diretamente contra os trabalhadores rurais revela um nível de ação que é o da interdição física na tentativa de impedi-los de fazer política e lutar por seus direitos. Contudo, as narrativas visuais e os editoriais publicados na imprensa e as discussões registradas na ata de reunião do IAA apresentam outros níveis. Por exemplo, quando jornalistas reconheciam que os trabalhadores rurais deveriam ter suas condições de vida melhoradas, como fez Costa Pôrto, editor-chefe do Diário de Pernambuco, que afirmou: "É visível o mal-estar [...] a convicção de que é necessário mudar coisa e mudar quanto antes [... ] a vida rural está sendo um inferno" (Diário de Pernambuco, 10/1/1963: 3). Esse reconhecimento, por parte do mesmo jornal que criminalizava os trabalhadores rurais e seus movimentos sociais, relacionava-se com a publicação das fotografias dos camponeses assassinados, as quais comprovavam o inferno no meio rural e criavam uma urgência de ação. Esta possibilitou aos representantes da elite agrária barganhar mais financiamentos de bancos públicos, buscar ampliar o apoio da opinião pública para as ações de repressão violenta no campo e se aproximar de setores do Exército. Entre janeiro de 1963 e março de 1964 essa dinâmica se intensificou cada vez mais, e o golpe civil-militar consolidou o projeto de poder e garantiu a impunidade da oligarquia rural. 


\section{NotAS}

1 Como elite agrária consideramos os senhores de engenho e os usineiros. Há distinções e tensões entre esses atores que, por extrapolarem os objetivos deste artigo, não serão analisadas. Elas podem ser lidas em Guillermo Palácio (2012-2013).

2 Quando estive no Sindicato dos Trabalhadores Rurais de Ribeirão, em julho de 2014, em busca de informações sobre conflitos na Usina Estreliana, fui recebido por alguns integrantes da diretoria. Foram eles que no meio de uma conversa informal me contaram histórias de violências praticadas por José Lopes de Siqueira Santos.

3 As informações sobre o que aconteceu com Antônio Farias, apresentadas no decorrer deste primeiro tópico do artigo, foram retiradas da reportagem intitulada Usina Estreliana: cinco mortos e três feridos num violento conflito ontem publicada pelo Jornal do Commercio em 8 de janeiro de 1963, p. 15. Arquivo Público Estadual Jordão Emerenciano - APEJE.

4 Ainda circulava em Pernambuco o jornal Última Hora - Nordeste. Criado em 1962, esteve aliado ao governo de Miguel Arraes e aos grupos de esquerda. Outro periódico, A Hora, era o de divulgação do PCB.

5 Além do Diário de Pernambuco, ver também o Jornal do Commércio de 14 de janeiro de 1960. Pág. 07.

6 Prontuário Funcional no 29177 - Liga Camponesa de Ribeirão. Arquivo Público Jordão Emerenciano - APEJE.

7 Entrevista com José Sebastião. Gameleira, 21 de julho de 2014.

8 Ainda sobre a repressão no campo, ver Campanha Nacional pela Reforma Agrária (CNRA), 1985.

9 Há referências a essas práticas na entrevista concedida por Francisco Julião à pesquisadora Eliana Mouri Fernandes, da Fundação Joaquim Nabuco, em 1982.

100 Instituto do Açúcar e do Álcool foi criado em 1933, pelo presidente Getúlio Vargas, como uma ação de intervenção do Estado na economia açucareira. Estabelecia um sistema de quotas de produção para cada uma das regiões açucareiras, garantia preços mínimos para o açúcar e o financiamento da produção (Oliveira, 1981). A ata da reunião realizada em 9 de janeiro de 1963 no Rio de Janeiro encontra-se na Biblioteca do Instituto Ricardo Brennand.

11 Ata da 1a Sessão 09.1.63. Instituto do Açúcar e do Álcool, Rio de Janeiro, 09 de janeiro de 1963. p. 2. Biblioteca do Instituto Ricardo Brennand.

12 Ata da 1a Sessão 09.1.63. Op. cit.

\section{REFERÊNCIAS BIBLIOGRÁFICAS}

CAlLADO, Antônio. Os industriais da seca e os "galileus" de Pernambuco. Rio de Janeiro: Civilização Brasileira, 1960.

Tempo de Arraes. A revolução sem violência. Rio de Janeiro: Paz e Terra, 1980.

CARNEIRO, Ana \& CIOCCARI, Marta. Retrato da repressão política no campo - Brasil 1962-1985: camponeses torturados, mortos e desaparecidos. Brasília: MDA, 2011.

CASTILLO TRONCOSO, Alberto del. Ensayo sobre el movimiento estudantil de 1968. La fotografia y la construcción de un imaginário. México: Instituto Mora/CONACYT/Instituto de Investigaciones Sobre La Universidad y La Educación, 2012.

DABAT, Christine Rufino. Uma caminhada penosa: a extensão do Direito trabalhista à zona canavieira de Pernambuco. Clio - Revista de Pesquisa Histórica, Recife, UFPE, 26-2, 2008. 
GAMARNIK, Cora. Imágenes de la ditadura militar. La fotografía de prensa antes, durante y después del golpe de Estado de 1976 en Argentina. In: FERNÁNDEZ, Silvia \& GAMARNIK, Cora. Artículos de investigación sobre fotografia. Montevideo: Ediciones CMDF, 2011.

El fotoperiodismo y la guerra de Malvinas: uma batalla simbólica. In: MAUAD, Ana \& MRAZ, John. Fotografía e historia. Montevideo: CFD Ediciones, 2015.

GOMES, Angela de Castro \& FERREIRA, Jorge. 1964: o golpe que derrubou um presidente, pôs fim ao regime democrático e instituiu a ditadura no Brasil. Rio de Janeiro: Civilização Brasileira, 2014.

GRUZINSKI, Serge. A guerra das imagens: de Cristóvão Colombo a Blade Runner (1492-2019). São Paulo: Companhia das Letras, 2016.

JULIÃO, Francisco. Cambão: a face oculta do Brasil. Recife: Ed. Bagaço, 2009.

KOSSOY, Boris. Imágenes y movimientos sociales brasileños a través de los archivos DEOPS/SP: Una radiografia. In: CASTILLO TRONCOSO, Alberto del \& MONROY NASR, Rebeca (coord.). Caminar entre fotones: formas y estilos de la mirada documental. México: Instituto Nacional de Antropología e Historia, 2013.

KOURY, Mauro Guilherme Pinheiro. Práticas instituintes e experiências autoritárias: o sindicalismo rural na mata pernambucana. Doutorado em Sociologia. Universidade Federal de São Carlos, SP, 2010.

MAGALHÃES, Fernanda Torres. O suspeito através das lentes. O DEOPS e a imagem da subversão, 1935-1945. São Paulo: Imprensa Oficial/Humanitas/FAPESP, 2008.

MONTENEGRO, Antonio Torres. Labirintos do medo: 0 comunismo (1950-1964). In Clio: Revista de pesquisa histórica, v. 22, 2004, p. 215-35.

História, metodologia, memória. São Paulo: Contexto, 2010.

. Trabalhadores rurais e Justiça do Trabalho em tempos de regime civil-militar. In: GOMES, Angela de Castro \& SILVA, Fernando Teixeira (org.). A Justiça do Trabalho e sua História. Campinas: Editora UNICAMP, 2013.

MRAZ, John. Ver fotografias historicamente. Uma mirada mexicana. In MAUAD, Ana \& MRAZ, John. Fotografía e historia. Montevideo: CFD Ediciones, 2015.

OLIVEIRA, Francisco de. Elegia para uma re(li)gião: SUDENE, Nordeste, Planejamento e conflito de classes. 3a ed. Rio de Janeiro: Paz e Terra, 1981.

PAGE, Joseph. A revolução que nunca houve. Rio de Janeiro: Record, 1972.

PALÁCIOS Y OLIVARES, Guillermo. Os plantadores de cana de Pernambuco na primeira metade do século XX: nascimento, crise e consolidação de uma "classe" agrária. Travesía: Revista de Historia Económica y Social, v. 14-15, 2012-2013, pp. 161-219.

PEREIRA, Anthony W. 0 declínio das Ligas Camponesas e a ascensão dos sindicatos. In: Clio - Revista de Pesquisa Histórica, Recife, UFPE, 26-2, 2009.

PORFIRIO, Pablo F. de A. Medo, comunismo e revolução: Pernambuco (1959-1964). Recife: Ed. da UFPE, 2009.

PORFIRIO, Pablo F. de A. Francisco Julião: em luta com seu mito. Golpe de Estado, exílio e redemocratização no Brasil. Jundiaí: Paco Editorial, 2016.

PROJETO MARCAS DA MEMÓRIA/UFPE. Entrevista com Fernando Barbosa. Recife, 18/10/2011.

VIANA, Gilney. Camponeses mortos e desaparecidos: excluídos da Justiça de transição. Brasília: Secretaria de Direitos Humanos da Presidência da República, 2013. 